\title{
Financial Security of Vietnamese Businesses and Its Influencing Factors
}

\author{
Van Cong NGUYEN*, Thi Ngoc Lan NGUYEN ${ }^{* *}$ \\ Received: November 17, 2019 Revised: December 11, 2019 Accepted: December 18, 2019
}

\begin{abstract}
This paper aims to not only investigate the nature of financial security and its measurement, but also to compare financial security level in 629 listed companies divided into four different industries (materials, industrials, health care, and consumer goods) before building a theoretical framework and regression models to examine the determinants of financial security. By gathering 2,167 financial statements published in Vietnamese Stock Exchange during eight years from 2012 to 2019, with the support of STATA, the research results indicate that six different internal factors, which are liquidity, profitability, firm size, debt management ratios, asset management ratios, and cash flows, explain $77.7 \%$ the change of financial security ratio and $3.4 \%$ the change in sustainable growth ratio. Specifically, while firm size has a positive impact on sustainable growth ratio but a negative impact on financial security ratio, deb management and profitability have an insignificant influence on the financial security level. Furthermore, an increase in asset management ratios would result positively in both two dependent variables whereas a rise in sustainable growth and a decline in financial security ratio are expected to witness if there is an increase in cash flows.
\end{abstract}

Keywords: Financial Growth, Financial Safety, Financial Security, Financial Stability, Vietnam

JEL Classification Code: G30, G32, L60.

\section{Introduction}

Financial security in business is always a hot topic that gets attention from not only business managers, banks, investors, but also a whole country. This interest is necessary and obvious because the financial security in business is an accurate measurement of financial stability, and it can reflect the potential development of the enterprise. From the investor's perspective, information on corporate financial security is one of the most value relevance helping investors assess the financial situation, thereby make appropriate predictions about the business's wealth before deciding whether to invest in this business or not (Minh, 2019). From the bank's perspective, assessing financial

*First Author and Corresponding Author. Professor, School of A ccounting and Auditing, The National Economics University (NE U), Vietnam [Postal Address: 207 Giai Phong, Dong Tam, Hai Ba Trung, Hanoi, 113068, Vietnam] Tel.: +84 913553456

Email: anhcongtuan@gmail.com; congnguyen@neu.edu.vn

${ }^{\star *}$ MSc Student, School of Economics, Finance and Managemen

$\mathrm{t}$, The University of Bristol, United Kingdom.

Email: nguyenthingoclan29071997@gmail.com

๑) Copyright: Korean Distribution Science Association (KODISA)

This is an Open Access article distributed under the terms of the Creative Commons Attribution NonCommercial License (https://creativecommons.org/licenses/by-nc/4.0/) which permits unrestricted non- security in a business is always a compulsory step in appraising the bank's loan application process because this is an indicator showing the ability of the business to recover that loan in the future. Finally, from the state management agencies, the financial security of businesses has a direct impact on the financial security and financial efficiency of a country since the national income of a country is dominantly generated from corporate income tax which rely mostly on financial performance of the businesses (Delas, Nosova, \& Yafinovych, 2015). Therefore, if an enterprise cannot ensure its security in finance, it would not only cause serious impression to its "going concern" status, but also result in many significant damages to shareholders, investors, banks, and other related parties as they probably lose all money invested in that enterprise.

After a series bankruptcy cases in large corporations namely Lehman Brothers Bank in 2008, Washington Mutual in 2008, WorldCom in 2002, or General Motors in 1998 leading to the elaboration of billions of dollars of investors and banks, research on financial security and its determinants is an urgent and essential topic. This is because one of the most common reasons leading to the collapse of these above corporations is that they are no longer able to maintain and control normal business 
activities as a result of losing financial security. Many researchers such as Baranovs'kyy (2004); Blank (2013); Muntiyan (1999); Pokropyvnyy (2001); and Shelest (2009) have emphasized the importance of financial security in businesses. However, these scholars offer a lot of different perspectives as well as different definitions about financial security. While Baranovs'kyy (2004) and Blank (2013) agree with the assumption that financial security is "the level of independence in financial resources which enough to meet the enterprise's needs and to fulfill existing obligations", the rest of researchers think that financial security is an indicator that not only measures the ability to pay due debts in the enterprise but also helps businesses with sustainable development. Some research by Le and Nguyen (2012), Nguyen, Nguyen, Tran, Dang, Pham, and Pham (2017), and Nguyen and Nguyen (2019) showed that financial security is one of the two sides that represent financial independence, reflects the state of safety as well as financial stability of the business.

From different points of view on the nature and role of financial security, there are several different assumptions about its driver factors. For example, from the viewpoint of ensuring financial security to certify the solvency in business, two different factor groups affecting financial security are found: (1) Internal (endogenous) factors include all indicators controlled by the business such as firm size, financial management, CEO intensity, and information accounting system (Delas, Nosova, \& Yafinovych, 2015); (2) External (exogenous) factors contain all factors related to businesses but they cannot control these factors such as political institutions, economic environment, technological development, and competition (Carson \& Hoyt, 1995). From the viewpoint of financial security referring to the stable operation and sustainable development of enterprises, any driver factors correlated to financial security must also affect the financial position of these enterprises. In other words, four different driver groups play an important role in shaping the financial security level in businesses. They are financial risk, economic positions, cash flows, and sustainable growth rates, which are determined by liquidity ratios, assets management ratios, cash flow operation, and profitability ratios (Delas, Nosova, \& Yafinovych, 2015).

Because of the turbulence and inconsistencies in previous research results, it led to confusion for other information users who were interested in financial security and its determinants. Moreover, the aforementioned studies stated above have been conducted in developed countries with significant differences in both macroeconomic conditions, institutional mechanisms and policy environment from Vietnam, so these studies are unlikely to be a suitable concept for Vietnamese businesses. In addition, the number of empirical studies examining this topic is really small because previous researchers seem to pay more attention to conducting an interpretivism study with a deeper understanding of financial security nature rather than focusing on building a causal relationship between driver factors and financial security with a positivism paper. Therefore, this paper will focus on address the contradictions by providing a clear definition of financial security and selecting the most appropriate factors to measure their impact on financial security.

In this research, we believe that it is necessary to evaluate the financial security level in business through three main points: risk detection ability, payment capacity, and development patentability. By observing 629 listed companies in Vietnam during eight-year-period, this paper can evaluate and compare the impact of six different independent variables including liquidity ratios (current ratios and quick ratio), cash flows (cash flows from operating activities, cash flows from investment activities, and cash flow from financial activities), profitability ratios (ROA, ROE, and ROS), debt management ratios (debt ratios), asset management ratios (inventory turnover ratios and fixed assets turnover ratio), and firm size, on the dependent variable measured through sustainable development ratio and financial security ratio in 629 published companies separated into 4 different industries.

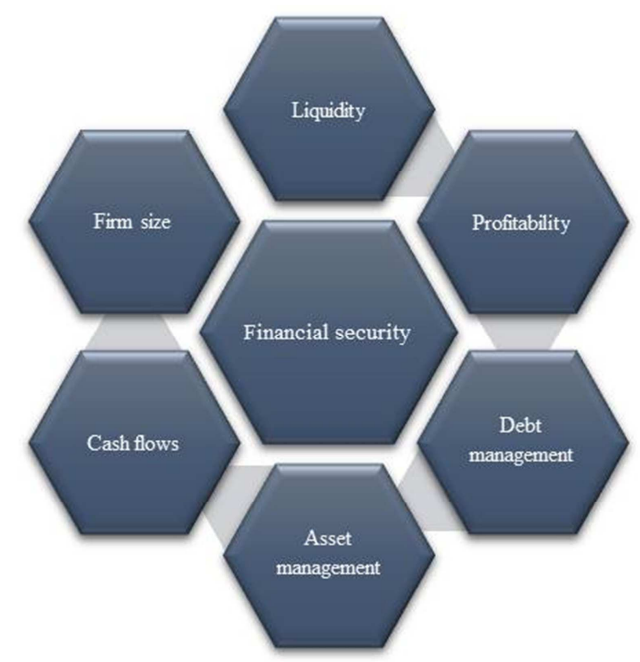

Figure 1: The determinants of financial security

Research data was collected from 2,167 financial statements of 629 companies listed on the Vietnamese Stock Exchange provided by the State Securities Commission of Vietnam. These companies were selected based on the availability of their annual reports between 2012 and 2019, then were grouped into four different industries based on Global Industry Classification Standards (MSCI, 2018): 235 consumer companies 
(consumer staples and consumer discretionary), 91 health care companies, 107 industrial companies (information technology, energy, and industrials), and 196 material companies. To ensure the representativeness, completeness, and reliability of the collected samples, data was collected based on the following criteria:

\section{Time period:}

The study period is between 2012 and 2019, when the Vietnam stock market witnessed positive changes in comparison with a downward trend in $\mathrm{VN}$-index between 2008 and 2012. This is because 2017 marked the beginning of unexpected success of Vietnam's economy when GDP accounted for $6.8 \%$, showing approximately $1 \%$ higher than the figure for the period of 2011-2016 with 5.96\% on average. Moreover, despite significant GDP growth, inflation is under control as a result of the Vietnamese Government's policy on prioritizing inflation management. The average CPI in 2017 increased only by $3.53 \%$ compared to 2016. This is a tremendous improvement in comparison with the crisis in 2008, when GDP increased to $8.48 \%$ and CPI rose to $8.3 \%$, leading to the transformation in listed companies in Vietnam.

\section{The samples:}

Samples are chosen from Vietnamese Stock exchanges. With 2167 observations in four different industries are conducted to get the best estimate. These industries are the biggest and most vital sectors in Vietnam, providing approximately $73 \%$ of total GDP in Vietnam in 2018 (General Statistics Office, 2018). Studying and grasping the financial situation of these four biggest economic Vietnamese industries are the key to help Vietnam's economy ensure financial stability and therefore, create opportunities for future development.

\section{The sources:}

Research data is collected from audited financial statements published by the State Securities Commission and securities companies. In order to ensure the reliability, transparency and accuracy of data sources, the authors compare all the information collected from financial statements from five different sources: Cophieu68 (2019); Hanoi Stock Exchange (2019); Ho Chi Minh Stock Exchange (2019); Cafef (2019); Finance.vietstock (2019).

\section{Literature Review}

Financial security in businesses is defined in many different ways, depending on the personal perspectives of the authors. Some argue that financial security simply demonstrates the ability of businesses to prevent financial risks such as insolvency (Blank, 2013; Baranovs'kyy, 2004; Carson \& Hoyt, 1995). Other authors, on the other hand, illustrate that financial security is not only for assessing payment risks, but also related to the stability and development ability of enterprises, showing the financial potential of enterprises in the present and in the future (Pokropyvnyy, 2001; Le \& Nguyen, 2012; Edmans, Fang, \& Zur, 2013; Arefiev, 2010). In fact, no matter how people look at it, the role in ensuring the "normal functioning" of financial security is obvious. Interestingly, from a philosophy perspective, Medvedyeva and Pohosova (2011), based on the "similarity in the purpose of existence" of a business with a person to develop a fascinating theory about financial security in businesses. Specifically, Medvedyeva and Pohosova (2011) said that "the need for secure of enterprise is on the second level of Maslow's hierarchy and it is a basis for implementation of higher-level needs". This is understandable because after the "physiological needs" (assets, and wealth), what any business needs is "safety" (financial security) before desiring to be "cared, recognized, or developed".

In the perspective of Zahorodniy and Voznyuk (2007), the financial security of a business is considered as a financial guarantee to pay interest rates on any loans or mortgages collected from suppliers, banks, tax authorities, and other creditors Financial security has a role "to provide safe and guaranteed investments in the company, to rise a product price over time, to reduce economic risks through low-quality products or service" (Rodionov, Spivak, Tertychna, Bondarenko, Popovychenko, \& Man'ko, 2011). Financial security is a degree of dependence on the financial costs arising in all financial or non-financial relationships of the enterprise or the degree to which financial resources are guaranteed to cover all financial needs in the enterprise (Baranovs'kyy, 2004). Financial security measures the level of financial capacity in terms of quality and quantity when the enterprise faces with financial risks and threats from inside or outside the enterprise, and also a level of driving force for the sustainable development of now and in the future (Blank, 2013).

Financial security shows the ability to eliminate risks for all business activities, including financial activities, investment activities, and payout decisions (Van'kovych, 2000). Financial security indicates the financial status in which businesses achieve a stable and balanced status when using financial resources, tools, and services to combat all internal and external financial threats and is also an effective financial tool to help businesses accomplish strategic goals for both profit and growth (Arefiev, 2010). Financial security in an enterprise is a complex process that involves in multiple levels of ensuring the financial activities safety out of negative bearings from both inside and outside the enterprise. These harmful effects could be a direct threat to "formation of its financial equilibrium in the current and strategic perspective". 
Therefore, guaranteeing financial security in businesses means promoting the efficiency of financial activities in the enterprise before up surging the market value (Voloschuk, 2004). This is an extremely important indicator of economic security in businesses, which is measured through independence, efficiency and competitiveness of enterprise's finance. It is expressed through the enterprise's willingness to pay debts, adequate liquidity of assets, and abundant cash flow to serve financial activities (Goryacheva, 2004). Financial security is an universal category, which reflects the security of subjects of social and economic relations at all levels, starting from the state and ending with each citizen, because it manifested through the protection of enterprise's activity from the adverse environmental effects, and the ability to remove quickly various threats or adapt to existing conditions which don't affect negatively on its activity (Kostak, 2016). Financial security along with financial autonomy demonstrates the degree of financial independence; in which, financial security indicates the level of financial safety and stability of enterprises (Le \& Nguyen, 2012; Nguyen \& Nguyen, 2019; Nguyen et al., 2017).

After reviewing these studies, we emphasize that financial security should be defined in all three dimensions: safety, stability, and growth. From the perspective of safety, businesses that are rated as having good financial security are those that have enough money to pay off all borrowing costs, interest rates to ensure the solvency of businesses in the short and long term. Secondly, financial security represents a state of financial stability, meaning that to achieve financial security, an enterprise needs to have a stable business environment (usually represented by cash flows) to independently make all three types of decisions: the financial investment decisions (are activities related to cost of capital, and the returns), the financing decisions (are activities related to debt and equity to maximizing firm values), and pay-out decisions (are activities correlated with cash flows, and dividend payment) (Berk \& DeMarzo, 2017). Finally, financial security is a sign of the potential growth of businesses in the present and in the future. In other words, "the company's financial security is a financial position and financial stability, which can provide effective development of enterprise activity" (Arefiev, 2010).

Theoretically, many researchers have analysed the relationship between different independent variables and financial security and from their research results, it can be said that these independent variables can be divided into three groups based on the nature and the impact of each group (Delas, Nosova, \& Yafinovych, 2015). The first group are macro factors including demographic factors (migration, marital status, gender, age, education), economic factors (Gross Domestic Products, availability of credits, interest rates, phase of economic cycles, and inflation), and cultural environment factors (adherence to tradition, subculture, religious, fashion, and social culture) (Back, Li, \& Ljungqvist, 2013; Delmar, Davidsson, \& Gartner, 2003). Although it is not possible to influence or control this group, the changes from the macroenvironment always have a great impact on the change of financial structure, business activities and thereby the financial security in the business. The second group of factors is the external microenvironment of an organization, which is correlated with five different partners (consumers, intermediaries, contact groups, suppliers, and competitors) (Carson \& Hoyt, 1995). This group of factors has a direct impact on the resources available to the enterprise, such as raw materials, technology, information, and labor, and thus, has a close relationship with the financial activities that take place in the business (Kramer, 1996; Soprano, 2015). The final group of factors that the research focuses on as well as businesses can forecast and control are internal factors, which are liquidity, solvency, profitability, debt management, asset management, and firm size (Delas, Nosova, \& Yafinovych, 2015; Back, Li, \& Ljungqvist, 2013; Bae, Kim, \& Oh, 2017).

Empirically, previous studies have focused on assessing the impact of endogenous factors on financial performance, on financial risks, or on business development rather than directly assessing factors affecting financial security. However, from the arguments and definitions above, the authors can assume that all endogenous factors related to financial risks, financial performance, and potential growth of the business can have an impact on the financial security of that business. More specific, Rushchyshyn, Rushchyshyn, and Kostak (2017) showed that if businesses want to achieve a balanced and stable status in their financial operations, these businesses have to develop a sound financial policy, in which liquidity is the key to creating financial strength for overcoming several financial pressures as well as monetary risks. Agreeing with that view, Capkun, Hameri, and Weiss (2009) said that one of the four most important group factors affecting financial strength in business is liquidity ratios, asset management ratios, debt management ratios, and profitability ratios. This is because profitability not only shows the performance of business activities in the past but also is a prediction of potential development for business in the future, while debt ratio is an important indicator determining the financial structure, thereby "shaping the degree of business financial stability and independence" (Berk \& DeMarzo, 2017). Buryak and Chalapko (2014) and Koknayeva (2013) showed that all endogenous factors including solvency, liquidity, and financial equilibrium are the most important measures for assessing the financial security since these factors are able to "satisfy the needs of the enterprise in financial resources 
for the sustainable expansion". Indeed, ensuring solvency and financial balance in the business is also the key to help businesses ensure financial independence (Nguyen et al., 2017); minimizing dangers and threats that can cause financial damage to the enterprise, before providing enough flexibility when making financial decisions. This would help the managers, creditors, and even shareholders with financial interest protection.

\section{Empirical Models and Research Methods}

\subsection{Hypothesis}

Based on previous studies on the impact of independent variables (liquidity ratios, asset management ratios, debt management ratios, profitability, cash flows, and firm size) on the financial security (financial security ratio, sustainable growth ratio) of businesses. This study puts forward the following hypotheses:

$\mathbf{H}_{\mathbf{0}}$ : Liquidity has a positive or negative correlation with the financial security.

Securing liquidity helps businesses "remain a sine through non" of any types of financial threats, helping enterprises with cash existence, wealth subsistence enough for overcoming monetary risks to maintain a balance of financial situation for other operation activities (Staubus, 1967). Agree with this view, many other researchers like Morrey and Guyton (2006), and Arefiev (2010) pointed out that managing liquidity in businesses not only helps businesses have a stable and sustainable business environment but also benefits businesses to attract more investors and banks, thereby increasing market value. Contrary to the above opinion, Back, Li, and Ljungqvist (2013), Maug (1998) or Edmans, Fang, and Zur (2013) have illustrated that the increase in liquidity leads to an increases the likelihood of "the large investors taking the Wall Street walk" but a lower level of block holder activism. This is because higher liquidity is harmful to governance, causing significant negative impacts on financial stability, and thereby negatively influencing financial security in businesses (Back, Li, \& Ljungqvist, 2013). Because of the inconsistencies in these research hypotheses, the author has not agreed on any literature above to decide the effect of liquidity on financial security in businesses.

$\mathbf{H}_{1}$ : Asset management ratios have a positive relationship with financial security.

From the perspective of inventory turnover, Capkun et al. (2009), Rajagopalan and Malhotra (2012), Vastag and
Whybark (2005), and Chen, Frank and Wu (2007) used empirical model to evaluate the impact of inventory turnover on the financial performance and found a significant positive correlation between these variables. Furthermore, through collecting a large sample size of manufacturing companies in US, Capkun et al. (2009) proved that inventory turnover significantly affects financial performance in the current and the following accounting period. About fixed asset turnover ratio, there are not too many in-depth studies on evaluating the importance of this indicator, especially for the financial security of enterprises. However, this indicator tells the manager how effectively a company generates sales using its fixed assets, so if a company has a higher fixed asset turnover ratio than its competitors, that company is using its fixed assets to generate sales better and more productive than its competitors (Green, 2019). Therefore, improving asset management ratios would normally help businesses strengthen financial security.

$\mathbf{H}_{2}$ : Debt management ratios negatively or positively impact on the financial security.

Bae, Kim, and Oh (2017) investigated the impact of financial leverage (determined by debt ratio) on firm performance (measured through Tobin's Q) and proved a Ushaped relationship between these two variables. This would mean that an increase in the proportion of debt could result in a significant decline in financial position of enterprise in some cases, but some time act as a better performance "leverage" (Semmler \& Bernard, 2012; Bae, Kim, \& Oh, 2017). However, any changes in financial leverage would consequently generate more financial risks because a firm's stability will increase up to an optimum point as leverage increases, and then decline if leverage is further increased beyond the optimum level (Carson \& Hoyt, 1995). Therefore, it is difficult for the authors in this research to conclude the impact of debt management ratios on financial security.

$\mathbf{H}_{3}$ : Profitability has a positive correlation with the financial security.

Profitability reveals dominantly not only the financial performance, but also the efficiency and effectiveness of business operations. As such, profitability becomes an essential indicator to evaluate the potential development and financial status of a business, which associates strongly in determining the financial security (Kim, Anderson, Amburgey, \& Hickman, 1995; Kramer, 1996). Specifically, Kramer (1996) found a significant positive impact of profitability on the financial solidity in Dutch non-life insurers as profitability plays an important role in shaping 
the financial stability for business, indicating the wealth strength of shareholders and the interests of investors. Thus, enhancing profitability would normally improve the financial security level in businesses.

\section{H5: Cash flows positively influence the financial security.}

Delas, Nosova, and Yafinovych (2015) show that cash flows have four different roles in securing financial capacity in businesses, namely: (1) reimbursement for production, marketing and services received, (2) financial obligations to the government, banks and other businesses, (3) formation of funds, and (4) implementation of financial and investment operations. This means that in order to maintain the balance and stability in the financial activities of the business, the manager must have the ability to control and regulate the cash flow appropriately, for simplicity. Without money, businesses will not be able to operate. Therefore, businesses with good financial capacity often keep their cash flows flowing steadily and are larger than businesses with lower cash flows during the period.

$\mathbf{H}_{6}$ : Firm size positively influences the financial security.
The financial security of any organization is influenced by, among other factors, the size or total assets of the firm (Kim, Anderson, Amburgey, \& Hickman, 1995). More specifically, large enterprises are always better able to control and regulate financial activities, thus ensuring better financial security than small businesses. This is explained by large enterprises that often have a lot of resources both economically and non-economically, thereby having a better capacity to undertake and remove financial risks (Arefiev, 2010). Although there are also many opposite views that smaller firms are more flexible in regulating financial resources, it is necessary to recognize that "larger firms have better prerequisites for behaviour compared to their smaller counterparts" (Omar, 2015). This is quite evident since large firms have a better ability to "access and use" financial resources both in breadth (the number of firm's financial partnerships) and depth (firm's influence on the financial partnerships), so it will be more proactive in regulating those financial resources to ensure financial security (Pais \& Stork, 2013).

\subsection{Empirical Model}

Table 1: Independent variables and dependent variables

\begin{tabular}{|c|c|c|}
\hline Variables & Meaning & Formula \\
\hline \multirow{2}{*}{ QUI } & \multirow{2}{*}{ Quick ratio - Independent variable } & Current assets - Inventory \\
\hline & & Current liability \\
\hline \multirow{2}{*}{ CUR } & \multirow{2}{*}{ Current ratio - Independent variable } & Current assets \\
\hline & & Current liability \\
\hline \multirow{2}{*}{ ROA } & \multirow{2}{*}{ Return on Assets- Independent variable } & Profit after tax \\
\hline & & Total assets \\
\hline \multirow{2}{*}{ ROE } & \multirow{2}{*}{ Return on Equity - Independent variable } & Profit after tax \\
\hline & & Equity \\
\hline \multirow{2}{*}{ ROS } & \multirow{2}{*}{ Return on Sales - Independent variable } & Profit after tax \\
\hline & & Sales \\
\hline \multirow{2}{*}{ DEB } & \multirow{2}{*}{ Debt ratio - Independent variable } & Total liabilities \\
\hline & & Total assets \\
\hline \multirow{2}{*}{ INV } & \multirow{2}{*}{ Inventory turnover ratio - Independent variable } & Sales \\
\hline & & Inventory \\
\hline \multirow{2}{*}{ FIX } & \multirow{2}{*}{ Fixed assets turnover ratio - Independent variable } & Sales \\
\hline & & Fixed assets -Accumulated depreciation \\
\hline SIZ & Firm size - Independent variable & Ln (total assets) \\
\hline $\mathrm{COA}$ & Cash flows from operating activities - Independent variable & $\mathrm{COA}$ \\
\hline CIA & Cash flows from investment activities - Independent variable & CIA \\
\hline CFA & Cash flows from financial activities - Independent variable & CFA \\
\hline \multirow{2}{*}{ SGR } & \multirow{2}{*}{ Sustainable development ratio - Dependent variable } & Revenue $_{t}-$ Revenue $_{(\mathrm{t}-1)}$ \\
\hline & & Revenue $_{(\mathrm{t}-1)}$ \\
\hline \multirow{2}{*}{ FSR } & \multirow{2}{*}{ Financial security ratio - Dependent variable } & Profit after tax + Depreciation \\
\hline & & Total liabilities \\
\hline
\end{tabular}

In this research, the authors use STATA and apply quantitative research into regression models, which comprise liquidity ratios (quick ratio and current ratio), profitability ratios (ROA, ROE, and ROS), firm size, asset management ratios (inventory turnover ratio and fixed-asset turnover ratio), debt management ratio (debt ratio), and cash flows (cash flows from operation activities, cash flows from investment activities, and cash flows from financial activities) as the independent variables and sustainable growth ratio (SGR) and financial security ratio (FSR) as 
dependent variables. The main regression models are developed in accordance with two different dependent variables:

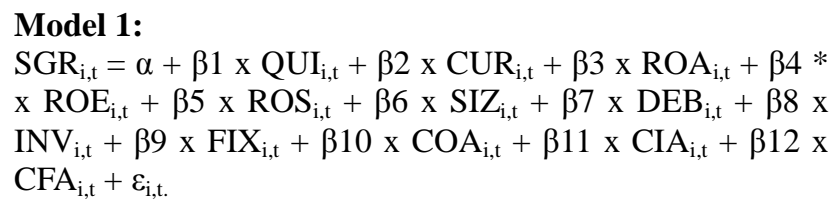

\section{Model 2:}

$\mathrm{FSR}_{\mathrm{i}, \mathrm{t}}=\alpha+\beta 1 \times \mathrm{QUI}_{\mathrm{i}, \mathrm{t}}+\beta 2 \times \mathrm{CUR}_{\mathrm{i}, \mathrm{t}}+\beta 3 \times \mathrm{ROA}_{\mathrm{i}, \mathrm{t}}+\beta 4 *$ $\mathrm{xRE}_{\mathrm{i}, \mathrm{t}}+\beta 5 \mathrm{xROS}_{\mathrm{i}, \mathrm{t}}+\beta 6 \mathrm{xSIZ}_{\mathrm{i}, \mathrm{t}}+\beta 7 \mathrm{xDEB}_{\mathrm{i}, \mathrm{t}}+\beta 8 \mathrm{x}$ $\mathrm{INV}_{\mathrm{i}, \mathrm{t}}+\beta 9 \mathrm{xIX}_{\mathrm{i}, \mathrm{t}}+\beta 10 \mathrm{xCOA}_{\mathrm{i}, \mathrm{t}}+\beta 11 \mathrm{x} \mathrm{CIA}_{\mathrm{i}, \mathrm{t}}+\beta 12 \mathrm{x}$ $\mathrm{CFA}_{\mathrm{i}, \mathrm{t}}+\varepsilon_{\mathrm{i}, \mathrm{t}}$

where: $\alpha, \beta 1, \beta 2, \beta 3, \beta 4, \beta 5, \beta 6, \beta 7, \beta 8, \beta 9, \beta 10, \beta 11$, and $\beta 12$ are coefficients

$\varepsilon$ is error

\subsection{Research Method}

This research is designed to compare the financial security level between industrials and investigate its drive factors including liquidity, profitability, firm size, asset management, debt management, and cash flows. In this research, we will follow both qualitative research by citing the scientific theories from previous studies and quantitative research into the correlation regression models and descriptive statistics. Moreover, to ensure the validity and reliability of data, sample collection and processing process will be outlined below:

Step 1: Selecting Subjects and Scopes of the Research.

Firstly, the authors examine all Vietnamese companies listed on the three biggest stock exchanges in Vietnam (HNX, HOSE, and UpCom). According to statistics provided by the State Security Commission of Vietnam, the total companies listed on these stock exchanges were 1553 until 31/09/2019; hence, this process selected a full list of 1533 companies with full names, stock codes and securities transactions.

The second step is classifying these companies into different industries and choosing all 832 companies from four different industries (consumer goods, health care, industrials, and materials) according to the Global Industry Classification Standard. These chosen companies include 301 consumer companies, 112 health care companies, 144 industrial companies, and 275 material companies.

\section{Step 2: Collecting Research Data}

In this step, the authors search for audited consolidated financial statements of all 832 companies between 2012 and 2019 from five different sources: Cophieu68 (2019); Hanoi Stock Exchange (2019); Ho Chi Minh Stock Exchange (2019); Cafef (2019); Finance.vietstock (2019) which are five the most popular and reputable websites for financial data. At the following stage, authors compare data collected from financial statements published on three various sources above to ensure the consistency for statistics eliminated all 57 companies that do not meet the consistency information requirement. The total number obtained is 2,896 financial statements.

Next, we verify the validity of financial statements data collected by checking the basic formula Total Assets = Current assets + Long-term assets $=$ Short-term liabilities + Long-term liabilities + Equity to remove 51 unsatisfactory observations. Finally, the dependent variables (SGR and FSR), and independent variables (QUI, CUR, ROA, ROE, ROS, DEB, INV, FIX, SIZ, COA, CIA, and CFA) are calculated before removing $1 \%$ extreme values to get the observation stability. The remaining observations are 2,167 (806 observations in consumer goods, 318 observations in health care, 355 observations in industrials, and 688 observations in materials).

\section{Step 3: Processing Research Data}

To increase the reliability of the research models, the authors perform both descriptive analysis and regression analysis with the support of STATA. Furthermore, in descriptive analysis, we will compare the differences in financial security, profitability, liquidity, asset management, cash flows, debt management, and firm size between industries before evaluating the impact of the independent variables on the dependent variables.

\section{Results}

\subsection{Descriptive Analysis}

To assess the changes in the financial security level of four different economic sectors including consumer goods, health care, industrials, and materials, the authors used Figures 2 and Figure 3. Figure 2 shows a significant difference in the sustainable growth between industries in the period of 2012-2019, Figure 3 compares the superiority in ensuring the financial security criteria in these industries in Vietnam during the given period. Generally, strong fluctuations in both financial security ratio and sustainable growth ratio were witnessed in all four industries in the given period, especially for industrial companies.

In Figure 2, the sustainable growth ratio of industrials was the highest level at the begging, which was replaced by health care at the end, as opposed to the least was recorded in consumer goods since 2018. Generally, a significant 
decline was seen in the sustainable growth of industrials, and consumer goods while fluctuation in an upward trend was seen in health care and materials. Starting at the same point of -0.2 in 2012 , the sustainable growth ratio of consumer goods and material increased significantly by 0.5 to approximately 0.3 in 2013 , after which while the figure for consumer goods declines steadily to the lowest level of 0.35 in the final year, the other figure fluctuated around 0.2 Industrials have a sustainable growth ratio of roughly 0.7 in 2012 , which was followed by a tremendous decrease to the lowest of 0 in 2015 and 2016 before witnessing a slight growth by 0.2 in 2018 . The figure for health care, on the other hand, increased gradually from under 0.1 in 2013 to 0.2 in 2017 before reaching a peak of 0.5 in 2018 .

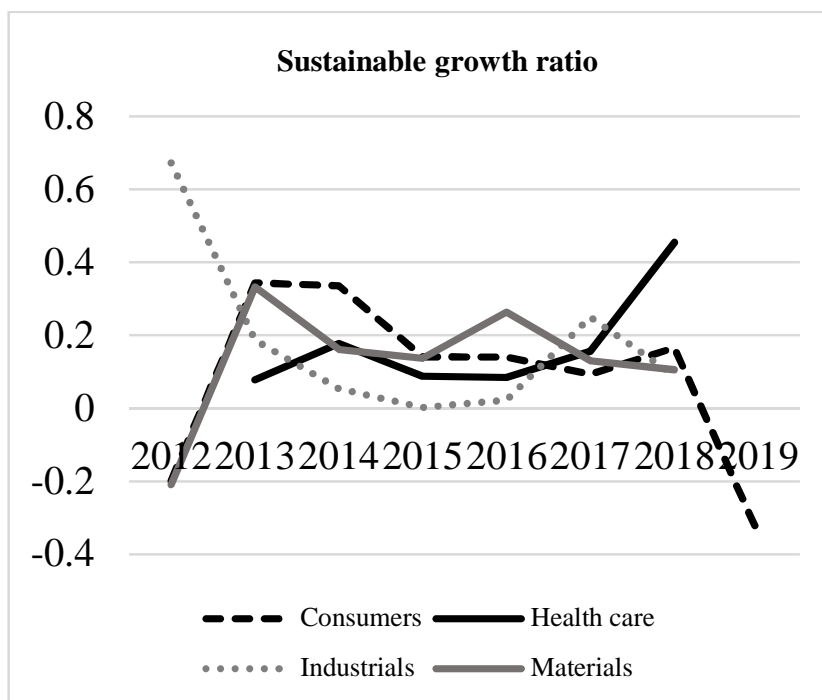

Figure 2: Sustainable growth ratio in four different industries between 2012 and 2019

Overall, look at Figure 3, it can be said that an improvement in financial security level was seen in all industries during the given period. While industrials seem to have the highest level of financial security in eight years, excepted for 2014 when the figure for health care accounted for the higher amount, the financial security ratio in consumer goods made up the lowest.

Specifically, financial security ratio of industrials accounted for 0.1 in 2012, showing 0.1 and 0.5 higher than the figures for materials and consumer goods respectively. From 2013 to 2014, a considerable decline of 0.3 was seen in the figure for industrials and materials as opposed to a significant increase in the other industries. 2016 witnessed a surge in financial security level of industrials from under 0.3 to approximately 1.8 , after that the figure plunged to the lowest point of roughly 0.3 in 2018 . The number of other industries, on the other hand, was on a reverse pattern of stability in an upward trend during the given period as it was on the same point of 0.25 in 2014 before increasing slightly by 0.1 in 2015 .

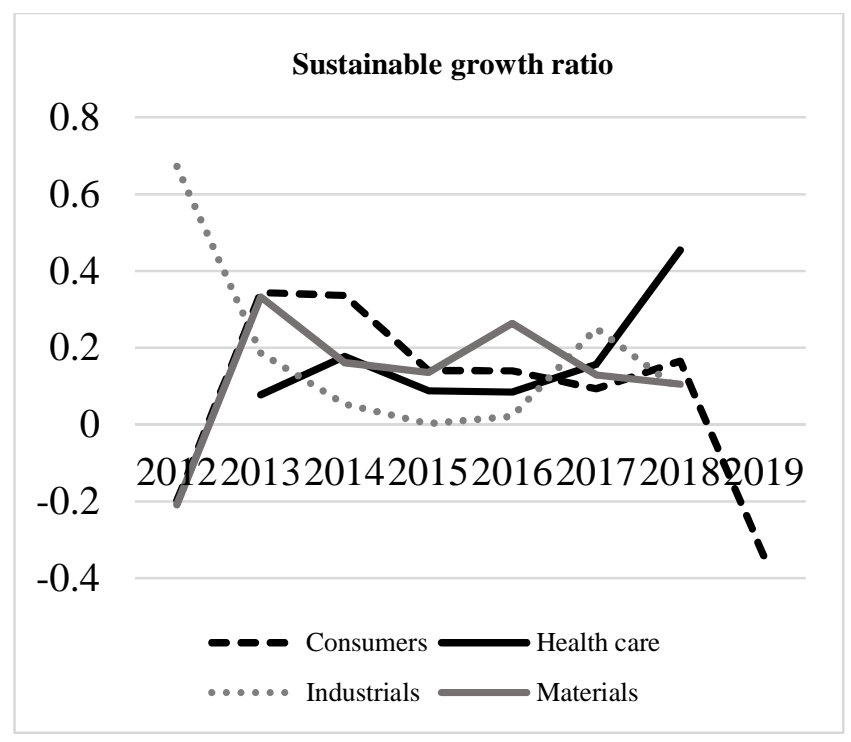

Figure 3: Financial security ratio in four different industries between 2012 and 2019

Table 2 illustrates mean, median, maximum, minimum, and number of all fourteen variables collected from 629 listed enterprises from 2012 to 2019. Overall, the industrials accounted for the highest average level of liquidity, which was replaced by health care for profitability as opposed to the least recorded in materials. The financial security level in health care made up the highest number with 0.127 for SGR and 0.232 for FSR, showing twice higher than the figure for industrials.

Firstly, for liquidity ratios, the mean of QUI and CUR in the consumer industry makes up 1.058 and 1.623 respectively, which are relatively lower than the figure for health care and industrials but significantly higher than that for materials with only 0.901 and 1.509 respectively. For profitability ratio, while the difference in ROA between industries is small, that in ROE and ROS is considerable. The dominant of funding in consumer and material is debt that accounts for $51 \%$ and $54.1 \%$ respectively, whereas the other industries are on the reverse pattern with a lower proportion of debt. Moreover, inventory turnover in consumer and industrials make up the highest level with 9.964 and 9.862 respectively in comparison with 6.757 in health care and 7.814 in materials. Finally, industrials have the smallest size but the highest asset management ratios while the consumer industry generates the largest cash flows from operation activities but the lowest cash flows from financial activities in average. 
Table 2: Descriptive analysis

\begin{tabular}{|c|c|c|c|c|c|c|c|c|c|c|c|c|c|c|}
\hline Variable & QUI & CUR & ROA & ROE & ROS & SIZ & DEB & INV & FIX & $\mathrm{COA}$ & CIA & CFA & SGR & FSR \\
\hline \multicolumn{15}{|c|}{ Consumer goods } \\
\hline Mean & 1.058 & 1.623 & 0.056 & 0.116 & 0.044 & 13.381 & 0.510 & 9.964 & 9.475 & 151811 & -113872 & 14726 & 0.114 & 0.162 \\
\hline Median & 0.796 & 1.260 & 0.041 & 0.102 & 0.035 & 13.294 & 0.528 & 6.650 & 4.965 & 23377 & -15186 & 43 & 0.053 & 0.082 \\
\hline Maximum & 5.973 & 6.709 & 0.416 & 1.192 & 0.529 & 17.787 & 0.939 & 133.358 & 227.105 & 9601595 & 1032687 & 3549849 & 4.860 & 2.114 \\
\hline Minimum & 0.046 & 0.091 & -0.297 & -0.546 & -1.324 & 9.650 & 0.046 & 0.419 & 0.101 & -368698 & -4130447 & -697002 & -1.000 & -0.857 \\
\hline Observations & 806 & 806 & 806 & 806 & 806 & 806 & 806 & 806 & 806 & 806 & 806 & 806 & 806 & 806 \\
\hline \multicolumn{15}{|c|}{ Heath care } \\
\hline Mean & 1.295 & 1.978 & 0.074 & 0.138 & 0.079 & 13.151 & 0.469 & 6.757 & 11.093 & 87713 & -61127 & 965 & 0.127 & 0.232 \\
\hline Median & 1.035 & 1.570 & 0.064 & 0.127 & 0.056 & 13.034 & 0.467 & 5.151 & 5.096 & 21110 & -11754 & -186 & 0.045 & 0.151 \\
\hline Maximum & 4.158 & 6.702 & 0.290 & 1.560 & 0.600 & 18.061 & 0.993 & 95.062 & 110.896 & 3938482 & 393932 & 1082635 & 5.870 & 1.355 \\
\hline Minimum & 0.129 & 0.212 & -0.217 & -1.001 & -0.482 & 10.993 & 0.109 & 0.482 & 0.223 & -320491 & -3203101 & -644909 & -0.761 & -0.403 \\
\hline Observations & 318 & 318 & 318 & 318 & 318 & 318 & 318 & 318 & 318 & 318 & 318 & 318 & 318 & 318 \\
\hline \multicolumn{15}{|c|}{ Industrials } \\
\hline Mean & 1.238 & 1.967 & 0.055 & 0.110 & 0.040 & 12.707 & 0.479 & 9.892 & 15.730 & 77740 & -43310 & 9898 & 0.057 & 0.187 \\
\hline Median & 0.967 & 1.647 & 0.044 & 0.097 & 0.032 & 12.534 & 0.435 & 5.468 & 7.055 & 6771 & -3424 & -508 & 0.047 & 0.089 \\
\hline Maximum & 5.857 & 6.550 & 0.336 & 0.507 & 0.742 & 17.963 & 0.990 & 135.270 & 220.204 & 9102453 & 499901 & 2470827 & 2.551 & 2.641 \\
\hline Minimum & -0.186 & 0.084 & -0.373 & -0.512 & -1.217 & 9.521 & 0.084 & 0.156 & 0.092 & -338636 & -1525187 & -729272 & -0.993 & -1.376 \\
\hline Observations & 355 & 355 & 355 & 355 & 355 & 355 & 355 & 355 & 355 & 355 & 355 & 355 & 355 & 355 \\
\hline \multicolumn{15}{|c|}{ Materials } \\
\hline Mean & 0.901 & 1.509 & 0.051 & 0.098 & 0.031 & 12.721 & 0.541 & 8.297 & 7.814 & 69934 & -45628 & 6677 & 0.126 & 0.141 \\
\hline Median & 0.725 & 1.240 & 0.042 & 0.105 & 0.035 & 12.632 & 0.543 & 5.350 & 4.675 & 9350 & -5639 & -31 & 0.068 & 0.076 \\
\hline Maximum & 4.535 & 6.692 & 0.445 & 0.813 & 0.599 & 17.319 & 0.994 & 133.151 & 109.316 & 6818720 & 995693 & 2185779 & 4.229 & 1.906 \\
\hline Minimum & -0.113 & 0.045 & $\begin{array}{ll}-0.657 \\
\end{array}$ & -1.139 & -1.332 & 7.985 & 0.058 & 0.031 & 0.049 & $\begin{array}{l}-381175 \\
\end{array}$ & -3763774 & -512945 & -0.901 & -1.667 \\
\hline Observations & 688 & 688 & 688 & 688 & 688 & 688 & 688 & 688 & 688 & 688 & 688 & 688 & 688 & 688 \\
\hline
\end{tabular}

\subsection{Correlation Analysis}

In order to estimate the correlation among 14 different variables grouped into seven collections: financial security
(SGR and FSR), liquidity (CUR and QUI), profitability (ROA, ROE, and ROS), firm size (SIZ), asset management ratios (INV and FIX), and cash flows (COA, CIA, and CFA).

Table 3: Correlation analysis

\begin{tabular}{|c|c|c|c|c|c|c|c|c|c|c|c|c|c|c|}
\hline & SGR & FSR & QUI & CUR & ROA & ROE & ROS & SIZ & DEB & INV & FIX & COA & CIA & CFA \\
\hline SGR & 1 & $0.133 *$ & -0.022 & -0.028 & $0.188 *$ & $0.177^{*}$ & $0.173^{*}$ & $0.140^{*}$ & $0.043 *$ & $0.070^{*}$ & 0.009 & $0.044 *$ & $-0.190^{*}$ & $0.091 *$ \\
\hline FSR & 0.002 & 1 & $0.481 *$ & $0.530^{*}$ & $0.939 *$ & $0.630^{*}$ & $0.864 *$ & $-0.054 *$ & $-0.602^{*}$ & $0.221 *$ & $0.208^{*}$ & $0.215^{*}$ & $-0.102 *$ & $0.059 *$ \\
\hline QUI & 0.002 & $0.826^{*}$ & 1 & $0.874^{*}$ & $0.328^{*}$ & 0.025 & $0.349 *$ & $-0.164 *$ & $-0.707^{*}$ & $0.222 *$ & $0.250^{*}$ & 0.007 & $0.076^{*}$ & $0.052 *$ \\
\hline CUR & 0.002 & $0.843^{*}$ & $0.994 *$ & 1 & $0.366^{*}$ & 0.027 & $0.349 *$ & $-0.203 *$ & $-0.785^{*}$ & -0.028 & $0.290^{*}$ & $-0.033^{*}$ & $0.093 *$ & 0.013 \\
\hline ROA & 0.000 & $0.468 *$ & 0.004 & 0.005 & 1 & $0.778^{*}$ & $0.863^{*}$ & 0.024 & $-0.400^{*}$ & $0.227 *$ & $0.243 *$ & $0.257 *$ & $-0.164 *$ & $0.070^{*}$ \\
\hline ROE & -0.000 & $0.197 *$ & -0.000 & -0.000 & $0.399 *$ & 1 & $0.613^{*}$ & $0.074^{*}$ & $0.041 *$ & $0.212 *$ & $0.219^{*}$ & $0.220^{*}$ & $-0.170^{*}$ & $0.078 *$ \\
\hline ROS & 0.001 & $0.138^{*}$ & -0.029 & -0.016 & $0.278 *$ & $0.121^{*}$ & 1 & $0.138^{*}$ & $-0.442 *$ & $0.069^{*}$ & -0.032 & $0.245^{*}$ & $-0.193^{*}$ & $0.077^{*}$ \\
\hline SIZ & -0.006 & 0.002 & $-0.046 *$ & $-0.041 *$ & $0.049 *$ & 0.002 & $0.036 *$ & 1 & $0.228 *$ & $-0.096^{*}$ & $-0.144^{*}$ & $0.333 *$ & $-0.404 *$ & 0.000 \\
\hline DEB & -0.005 & -0.026 & $-0.045^{*}$ & $-0.041 *$ & $-0.152^{*}$ & -0.000 & $-0.094 *$ & $-0.037 *$ & 1 & $-0.097 *$ & $-0.034 *$ & $-0.052 *$ & $-0.087^{*}$ & 0.010 \\
\hline INV & -0.002 & 0.016 & 0.018 & 0.007 & -0.011 & -0.001 & 0.010 & $-0.040^{*}$ & 0.031 & 1 & $0.200^{*}$ & $0.157^{*}$ & 0.003 & 0.024 \\
\hline FIX & -0.004 & -0.012 & $0.077^{*}$ & $0.051^{*}$ & -0.001 & 0.013 & 0.001 & -0.015 & -0.017 & 0.004 & 1 & $-0.109 *$ & $0.098^{*}$ & -0.029 \\
\hline $\mathrm{COA}$ & -0.003 & 0.004 & -0.010 & -0.010 & 0.016 & 0.004 & 0.015 & $0.340^{*}$ & -0.020 & -0.009 & -0.018 & 1 & $-0.294 *$ & $0.196 *$ \\
\hline CIA & 0.001 & 0.005 & 0.008 & 0.008 & -0.005 & -0.003 & -0.009 & $-0.285^{*}$ & 0.001 & 0.010 & 0.006 & $-0.493 *$ & 1 & $0.086^{*}$ \\
\hline CFA & 0.001 & -0.001 & 0.001 & 0.002 & -0.003 & -0.003 & -0.004 & $-0.097 *$ & 0.009 & -0.000 & -0.007 & $-0.218^{*}$ & $-0.072 *$ & 1 \\
\hline
\end{tabular}

Overall, it can be said that liquidity ratios and profitability ratios have a strong relationship with FSR as opposed to a weak correlation with other independent variables. Furthermore, while firm size, debt management ratio, and asset management ratio have a negative impact on SGR, the other independent variables are on the reverse 
pattern. Finally, an autocorrelation may exist in the two models stated above when the relationships between profitability and debt management ratio, and between profitability and liquidity are significant with approximately 0.4 and 0.3 respectively.

The strongest correlation among variables is between quick ratio and current ratio, which is followed by the relationship between these two variables and FSR. Additionally, while liquidity has a strong relationship with FSR, firm size, debt management ratio, asset management ratio and cash flows influence the dependent variables infinitesimally. However, the correlation between these dependent variables and cash flows are generally positive but insignificant in comparison with a significant positive impact of profitability on these dependent variables.

\subsection{Regression Models}

In order to conduct an accurate measurement for the impact of 6 independent variables on 2 dependent variables (SGR and FSR), the author will use STATA version 2015 to implement the two regression models - FEM (Fixed Effect Model) and REM (Random Effect Model) with the data panel collected from 629 enterprises. The difference between REM and FEM is seen in a variety of units. In other words, while the variation of units is correlated with the independent variables in FEM, whereas that in REM is assumed to be random and incompatible with independent variables.

Table 4: Regression analysis

\begin{tabular}{|c|c|c|c|c|}
\hline & (SGR) & (SGR) & (FSR) & (FSR) \\
\hline VARIABLES & FEM & REM & FEM & REM \\
\hline \multirow[t]{2}{*}{ QUI } & -0.0127 & 0.0373 & -0.00395 & -0.0120 \\
\hline & $(0.0536)$ & $(0.0325)$ & $(0.0106)$ & $(0.00787)$ \\
\hline \multirow[t]{2}{*}{ CUR } & 0.00566 & -0.0460 & $0.0699 * * *$ & $0.0740 * * *$ \\
\hline & $(0.0473)$ & $(0.0282)$ & $(0.00933)$ & $(0.00685)$ \\
\hline \multirow[t]{2}{*}{ ROA } & $0.776^{*}$ & 0.0416 & $3.700 * * *$ & $3.838 * * *$ \\
\hline & $(0.441)$ & $(0.305)$ & $(0.0869)$ & $(0.0705)$ \\
\hline \multirow[t]{2}{*}{ ROE } & 0.245 & $0.264 * *$ & $-0.547 * * *$ & $-0.571 * * *$ \\
\hline & $(0.174)$ & $(0.122)$ & $(0.0342)$ & $(0.0280)$ \\
\hline \multirow[t]{2}{*}{ ROS } & $-0.337 * *$ & -0.00884 & $0.0956 * * *$ & $0.126 * * *$ \\
\hline & $(0.168)$ & $(0.122)$ & $(0.0332)$ & $(0.0276)$ \\
\hline \multirow[t]{2}{*}{ SIZ } & $0.238 * * *$ & 0.0141 & $-0.0251 * * *$ & -0.00155 \\
\hline & $(0.0482)$ & $(0.0109)$ & $(0.00951)$ & $(0.00304)$ \\
\hline \multirow[t]{2}{*}{ DEB } & 0.0492 & -0.00940 & 0.0437 & 0.0333 \\
\hline & $(0.182)$ & $(0.0915)$ & $(0.0359)$ & $(0.0231)$ \\
\hline \multirow[t]{2}{*}{ INV } & $0.00295^{*}$ & 0.000927 & $4.84 \mathrm{e}-05$ & 0.000330 \\
\hline & $(0.00158)$ & $(0.00103)$ & $(0.000311)$ & $(0.000244)$ \\
\hline \multirow[t]{2}{*}{ FIX } & $0.00267 *$ & -0.000285 & -0.000915 *** & $-0.000854 * * *$ \\
\hline & $(0.00139)$ & $(0.000724)$ & $(0.000273)$ & $(0.000184)$ \\
\hline \multirow[t]{2}{*}{$\mathrm{COA}$} & $-1.59 \mathrm{e}-08$ & $-5.12 \mathrm{e}-08 *$ & $8.22 \mathrm{e}-09$ & $1.32 \mathrm{e}-08 * *$ \\
\hline & $(4.84 \mathrm{e}-08)$ & $(2.66 \mathrm{e}-08)$ & $(9.54 \mathrm{e}-09)$ & (6.60e-09) \\
\hline \multirow[t]{2}{*}{ CIA } & $8.64 \mathrm{e}-09$ & $-4.39 \mathrm{e}-08$ & $-1.09 \mathrm{e}-09$ & $9.35 \mathrm{e}-09$ \\
\hline & $(6.45 e-08)$ & $(4.20 \mathrm{e}-08)$ & $(1.27 \mathrm{e}-08)$ & $(9.76 \mathrm{e}-09)$ \\
\hline \multirow[t]{2}{*}{ CFA } & $3.88 \mathrm{e}-08$ & $7.00 \mathrm{e}-08$ & $-1.39 \mathrm{e}-08$ & $1.02 \mathrm{e}-09$ \\
\hline & $(8.42 \mathrm{e}-08)$ & $(6.50 \mathrm{e}-08)$ & $(1.66 \mathrm{e}-08)$ & $(1.43 \mathrm{e}-08)$ \\
\hline \multirow[t]{2}{*}{ Constant } & $-3.120 * * *$ & -0.0664 & $0.215^{*}$ & $-0.0945 * *$ \\
\hline & $(0.614)$ & $(0.150)$ & $(0.121)$ & $(0.0411)$ \\
\hline Observations & 2,167 & 2,167 & 2,167 & 2,167 \\
\hline Number of Units & 629 & 629 & 629 & 629 \\
\hline R-squared & 0.034 & & 0.777 & \\
\hline
\end{tabular}

Table 4 shows the regression results for the SGR model and FSR model in terms of Fixed Effects and Random Effects. Generally, with the confidence level of $95 \%$, it can be said that the independent variables are able to explain $3.4 \%$ of the changes in SGR and $77.7 \%$ of the changes in FSR as a result of $\mathrm{R}^{2}$ analysis. Furthermore, while firm size has a significant positive impact on SGR but the significant negative impact on FSR, deb management and profitability have an insignificant influence on the financial security. INV and FIX significantly and positive effect in both two dependent variables whereas CIA and CFA positively impact on SGR but negatively impact on FSR.

In order to determine and evaluate the reliability and rationality of this model, it is necessary to use the following 
tests:

Hausman Test to choose between FEM or REM model

Because the P-value (Hausman test of SGR model) = $0.0000<0.05 \rightarrow \mathrm{H}_{0}$ is rejected $\rightarrow$ FEM model is chosen for SGR model

Because the P-value (Hausman test of FSR model) = $0.0000<0.05 \rightarrow \mathrm{H}_{0}$ is rejected $\rightarrow$ FEM model is chosen for FSR model.

In conclusion, the FEM model is suitable for both SGR model and FSR model.

Test of changes in autocorrelation

Because P-value $_{(\mathrm{SGR} \text { model })}=0.2181>0.05 \rightarrow$ SGR model has no autocorrelation

Because P-value $_{(\text {FSR model })}=0.1014>0.05 \rightarrow$ FSR model has no autocorrelation

Test of changes in error variances

Because P-value $_{(\text {SGR model) }}=0.1621>0.05 \rightarrow$ SGR model does not have any change in error variances.

Because P-value $($ FSR model $)=0.0853>0.05 \rightarrow$ FSR model does not have any change in error variances.

Through the implementation of the above tests, the author has found a relationship between six independent variables to two dependent variables as shown below:

\section{Model 1:}

$\mathrm{SGR}_{\mathrm{i}, \mathrm{t}}=-3.120-0.0127 \times \mathrm{QUI}_{\mathrm{i}, \mathrm{t}}+0.00566 \times \mathrm{CUR}_{\mathrm{i}, \mathrm{t}}+0.776$ $\mathrm{x} \mathrm{ROA}_{\mathrm{i}, \mathrm{t}}+0.245 * \mathrm{x} \mathrm{ROE}_{\mathrm{i}, \mathrm{t}}-0.337 \mathrm{x} \mathrm{ROS}_{\mathrm{i}, \mathrm{t}}+0.238 \mathrm{x} \mathrm{SIZ}_{\mathrm{i}, \mathrm{t}}$ $+0.0492 \times \mathrm{DEB}_{\mathrm{i}, \mathrm{t}}+0.00295 \times \mathrm{INV}_{\mathrm{i}, \mathrm{t}}+0.00267 \mathrm{x} \mathrm{FIX}_{\mathrm{i}, \mathrm{t}}-$ $1.59 \times 10^{-8} \times \mathrm{COA}_{\mathrm{i}, \mathrm{t}}+8.64 \times 10^{-9} \times \mathrm{CIA}_{\mathrm{i}, \mathrm{t}}+3.88 \times 10^{-8} \mathrm{x} \mathrm{CFA}_{\mathrm{i}, \mathrm{t}}$ $+\varepsilon_{i, t}$

\section{Model 2:}

$\mathrm{FSR}_{\mathrm{i}, \mathrm{t}}=-0.0945-0.0120 \times \mathrm{QUI}_{\mathrm{i}, \mathrm{t}}+0.0740 \times \mathrm{CUR}_{\mathrm{i}, \mathrm{t}}+3.838$ $\mathrm{x} \mathrm{ROA}_{\mathrm{i}, \mathrm{t}}-0.571 \times \mathrm{ROE}_{\mathrm{i}, \mathrm{t}}+0.126 \mathrm{x} \mathrm{ROS}_{\mathrm{i}, \mathrm{t}}-0.00155 \mathrm{x} \mathrm{SIZ}_{\mathrm{i}, \mathrm{t}}$ $+0.0333 \times \mathrm{DEB}_{\mathrm{i}, \mathrm{t}}+0.000330 \times \mathrm{INV}_{\mathrm{i}, \mathrm{t}}-0.000854 \times \mathrm{FIX}_{\mathrm{i}, \mathrm{t}}$ $+1.32 \times 10^{-8} \mathrm{x} \mathrm{COA}_{\mathrm{i}, \mathrm{t}}+9.35 \times 10^{-9} \mathrm{x} \mathrm{CIA}_{\mathrm{i}, \mathrm{t}}+1.02 \times 10^{-9} \mathrm{x} \mathrm{CFA}_{\mathrm{i}, \mathrm{t}}$ $+\varepsilon_{\mathrm{i}, \mathrm{t}}$

\section{Conclusions}

From the hypothesis built in Part 3.2 and the regression analysis presented in 4.3 , it can be said that there are many differences in relationship among variables in expectations and, which are summarized in Table 5.

From Table 5, six internal drive factors measuring liquidity, profitability, firm size, asset management, debt management, and cash flows have a direct and significant impact on the financial security in businesses. They are able to explain more than $77.7 \%$ of the changes in financial security level and $3.4 \%$ of the changes in sustainable growth of the businesses.
Table 5: The impact of six different factors on the financial security

\begin{tabular}{|c|c|c|c|}
\hline Variable & Expectation & SGR & FSR \\
\hline QUI & $?$ & -, insignificant & -, significant \\
\hline CUR & ? & + , significant & + , significant \\
\hline ROA & + & + , insignificant & + , insignificant \\
\hline ROE & + & + , insignificant & -, significant \\
\hline ROS & + & -, insignificant & + , significant \\
\hline SIZ & + &,+ significant & -, significant \\
\hline DEB & $?$ & + , insignificant & + , significant \\
\hline INV & + &,+ significant & + , significant \\
\hline FIX & + & + , significant & - , significant \\
\hline $\mathrm{COA}$ & + & -, significant & + , significant \\
\hline CIA & + & + , significant & + , significant \\
\hline CFA & + &,+ significant & + , significant \\
\hline \multicolumn{4}{|c|}{$+:$ positive } \\
\hline & & negative & \\
\hline
\end{tabular}

Specifically, an increase in quick ratio could result in a significant decline in both sustainable growth ratio and financial security ratio while an improvement in current ratio, return on assets, debt ratio, inventory turnover, cash flows from investment activities, and cash flows from financial activities would help businesses with a positive change in financial security situation. However, if ROS and cash flows from operation activities increase, a downward trend in sustainable growth would normally be witnessed as opposed to an upgrade in financial security level.

\section{References}

Arefiev, V. (2010). The strategy of providing financial security of the enterprise as a guarantee of its effective and stable functioning. Bulletin of the Economy of Transport and Industry, 29, 65-68.

Back, K., Li, T., \& Ljungqvist, A. (2013). Liquidity and Governance. Cambridge, England: National Bureau of Economic Research.

Bae, J., Kim, S.-J., \& Oh, H. (2017, April). Taming polysemous signals: The role of marketing intensity on the relationship between financial leverage and firm performance. Review of Financial Economics, 33, 29-40. https://doi.org/10.1016/j.rfe.2016.12.002

Baranovs'kyy, I. O. (2004). Financial security in Ukraine (methodology of the Zinc and the mechanism of security). Kiev, Ukraine: KNTEU.

Berk, J., \& DeMarzo, P. (2017). Corporate Finance (Global Edition ed., Vol. III). (S. University, Ed.) Essex, England: Pearson Education Limited.

Blank, A. I. (2013, January). Management of financial security of the enterprise. Retrieved July 16, 2019, from http://econjournal.vsau.org/files/pdfa/2114.pdf 
Buryak, P., \& Chalapko, L. (2014). Financial Planning in Providing Financial Security at Enterprises. Scientific Bulletin of Kherson State University, 9(1), 112-115.

Cafef. (2019, 9 12). Enterprise data. Retrieved from http://s.cafef.vn/du-lieu-doanh-nghiep.chn

Capkun, V., Hameri, A., \& Weiss, L. A. (2009). "On the relationships between inventory and financial performance in manufacturing companies. International Journal of Operations and Production Management, 29(8), 789-806.

Carson, J. M., \& Hoyt, R. E. (1995). Life Insurer Financial Distress: Classification Models and Empirical Evidence. Journal of Risk and Insurance, 62(4), 764-775. DOI: $10.2307 / 253595$.

Chen, H., Frank, M. Z., \& Wu, O. Q. (2007). US retail and wholesale inventory performance from 1981 to 2004. Manufacturing and Service Operations Management, 9(4), 430-456.

Cophieu68. (2019). List of listed companies. Retrieved from https://www.cophieu68.vn/companylist.php

Delas, V., Nosova, E., \& Yafinovych, O. (2015). Financial Security of Enterprises. Procedia Economics and Finance, 27, 248-266. doi: 10.1016/S22125671(15)00998-3.

Delmar, F., Davidsson, P., \& Gartner, W. (2003, March). Arriving at the High-Growth Firm. Journal of Business Venturing, 18(2), 189-216. doi:10.1016/S08839026(02)00080-0

Edmans, A., Fang, V. W., \& Zur, E. (2013, June). The Effect of Liquidity on Governance. European Corporate Governance Institute (ECGI) - Finance Working Paper No. 319/2011, 26(6), pp. 1443-1482. Retrieved from https://papers.ssrn.com/sol3/papers.cfm?abstract_id=19 05224

Finance.vietstock. (2019). Shareholder documents. Retrieved from https://finance.vietstock.vn/tai-lieu/baocao-tai-chinh.htm

General Statistics Office. (2018). Overview of Vietnamese economy in 2018. Hanoi, Vietnam: General Statistics Office. $\quad$ Retrieved from https://www.gso.gov.vn/default.aspx?tabid=382\&idmid $=2 \&$ ItemID $=19041$

Goryacheva, K. (2004, January). Estimating the level of financial security of the enterprise. Bulletin of economy of transport and industry, 29, 127-130. Retrieved from http://dspace.uabs.edu.ua/jspui/bitstream/123456789/31 59/1/Gorjacheva.pdf

Green, L. (2019, September 19). Fixed Asset Turnover Ratio. Retrieved November 10, 2019, from https://www.investopedia.com/ask/answers/033015/wha t-considered-be-good-fixed-asset-turnover-ratio.asp
Hanoi Stock Exchange. (2019, 11 02). Stock list. Retrieved November 13 2019, from https://www.hnx.vn/vivn/cophieu-etfs/chung-khoan-ny.html

Ho Chi Minh Stock Exchange. (2019, 11 03). List of listed companies on Ho Chi Minh Stock Exchange. Retrieved November 10, 2019, from https://www.hsx.vn/Modules/Listed/Web/Symbols?fid= 9ac914fbe9434adca2801e30593d0ae2

Kim, Y.-D., Anderson, D. R., Amburgey, T. L., \& Hickman, J. C. (1995). The Use of Event History Analysis to Examine Insurer Insolvencies. Journal of Risk and Insurance, 62(1), 94-110. Retrieved from https://search.proquest.com/openview/e0ce4622b81ce4 $\mathrm{d} 214 \mathrm{c} 6056 \mathrm{de} 4 \mathrm{a} 21 \mathrm{~b} 16 / 1$ ?pqorigsite $=$ gscholar \&cbl $=4851$ 1

Koknayeva, O. (2013). Peculiarities of the Methodological Toolkit for the Study of the Financial-Economic Security of Trade Enterprises. Retrieved September 20, 2019, from http://wwwpokaznyk_ocinky_.pdf

Kostak, Z. (2016, January). The role of financial and economic security in the strategic development of entrepreneurial structures. Visnyk of Lviv Trade and Economic University, 51, 149-155.

Kramer, B. (1996). An Ordered Logit Model for the Evaluation of Dutch Non-Life Insurance Companies. De Economist, 144(1), 79-91.

Le, A. T., \& Nguyen, C. V. (2012). Discussion on general assessment of the level of financial independence of enterprises under the economic \& legal perspective. Economics and Development, NEU, III, Special December, 76-79.

Maug, E. (1998). Large Shareholders as Monitors: Is There a Trade-Off between Liquidity and Control? The Journal of Finance, 53(1), 65-98. https://doi.org/10.1111/0022- 1082.35053.

Medvedyeva, B. I., \& Pohosova, M. Y. (2011). Diagnosis of industrial safety in a three-tier system of financial relations. Retrieved September 12, 2019, from http://elibrary.ru/item.asp?id=21309581.

Minh, H. (2019, September 16). Business grows fast, but must be sustainable. Retrieved from https://tinnhanhchungkhoan.vn/thoi-su/doanh-nghiepphat-trien-nhanh-nhung-phai-ben-vung-278805.html

Morrey, J., \& Guyton, A. (2006). Liquidity, interest rates and banking. In A. Guyton, Liquidity, Interest Rates and Banking (pp. 3-33). Omaha, NE: Nova Science Publishers.

MSCI. (2018). The Global Industry Classification Standard (GICS®). Retrieved from https://www.msci.com/gics

Muntiyan, I. V. (1999). The economic security of Ukrayina. Kiev, Ukraine: KVITs.

Nguyen, C. V., \& Nguyen, L. T. (2019). Factors affecting the level of financial independence of listed 
manufacturing companies: Evidence from Vietnam. International Journal of Business, Economics and Law, 18(5), 167-178. $\quad$ Retrieved from https://www.ijbel.com/wpcontent/uploads/2019/05/ijbel5-VOL18_280.pdf.

Nguyen, C. V., Nguyen, C. T., Tran, D. M., Dang, H. T., Pham, K. X., \& Pham, T. T. (2017). Textbook of Financial Statements Analysis. Hanoi, Vietnam: National Economics University Press.

Omar, H. (2015, October). The relationship between firm size and financial performance of microfinance banks in Kenya. Nairobi, Kenya: University of Nairobi. Retrieved from https://pdfs.semanticscholar.org/4a2e/b75906f29272271 d9fb049995e19bc809f10.pdf

Pais, A., \& Stork, P. A. (2013). Bank size and systemic risk. European Financial Management, European Financial Management Association, 19(3), 429-451. https://doi.org/10.1111/j.1468-036X.2010.00603.x.

Pokropyvnyy, F. S. (2001). Economics of Giving. Kiev, Ukraine: Vyd-vo KNEU.

Rajagopalan, S., \& Malhotra, A. (2012). "Have US manufacturing inventories really decreased? An empirical study. Manufacturing and Service Operations Management, 3(1), 14-24.

Rodionov, V. O., Spivak, I. S., Tertychna, V. N., Bondarenko, S. O., Popovychenko, S. H., \& Man'ko, M. I. (2011). Formation of financial security of enterprise. Noulidzh, Ukraine: Luhans'k Vyd-vo.

Rushchyshyn, N., Rushchyshyn, N., \& Kostak, Z. (2017, September). Formation of financial security of the enterprise based on strategic planning. Baltic Journal of Economic Studies, 3(4), 231-237. doi:10.30525/22560742/2017-3-4-231-237
Semmler, W., \& Bernard, L. (2012). Boom-bust cycles: Leveraging, complex securities, and asset prices. Journal of Economic Behavior \& Organization, 81(2), 442-465. Retrieved from https://doi.org/10.1016/j.jebo.2011.07.002

Shelest, V. (2009). Managing the financial security of utterly good fidelity. Aktual'ni problemy ekonomiky, 3(93), 181-185.

Soprano, A. (2015). Liquidity Risk in the Financial Crisis: A Funding Risk Handbook. In A. Soprano, A Funding Risk Handbook (pp. 16-23). Cornwall, England: John Wiley \& Sons.

Staubus, G. J. (1967). Cash Flow Accounting and Liquidity: Cash Flow Potential and Wealth. In C. 1. Characteristics, Liquidity Risk Management (pp. 1-16). London, UK: Banker's Publishing Company.

Van'kovych, D. (2000). Securing financial security in the process of inculcating the financial resources management system. The economical system of Ukraine: European's choice. Ekonomichna systema Ukrayiny: yevropeys'kyy vybir: mat-ly mizh nar. nauk. konf. L'viv, LNU im. I. Franka, 11-12.

Vastag, G., \& Whybark, D. (2005). Inventory management: is there a knock-on effect? International Journal of Production Economics, 93-94(1), 129-138.

Voloschuk, L. (2004). Economic Security and Innovative Development of an Industrial Enterprise: The Essence and Interconnection as Objects of Management. Economics: Realities of Time, 6(16), 217-223. Retrieved from http://dspace.uabs.edu.ua/jspui/bitstream/123456789/31 59/1/Gorjacheva.pdf

Zahorodniy, A. H., \& Voznyuk, H. L. (2007). Finansovoekonomichnyy slovnyk. Kiev, Ukraine: Znannya. 